\title{
Correction to: Characterization of the inhibition mechanism of a tissue factor inhibiting single-chain variable fragment: a combined computational approach
}

\author{
Jan-G Vermeulen $^{1,2}$ (D) Felicity Burt ${ }^{3,4}$ D $\cdot$ Esta van Heerden ${ }^{1} \cdot$ Louis Lategan du Preez $^{1}$ (D) Muriel Meiring ${ }^{2,4}$ (D \\ Published online: 3 May 2020 \\ (C) Springer-Verlag GmbH Germany, part of Springer Nature 2020
}

Correction to: Journal of Molecular Modeling (2020) 26:87 https://doi.org/10.1007/s00894-020-4350-7

One of the co-author's details (Leon du Preez-lategaan) was printed incorrectly in the above publication. The correct details are provided below.

Louis Lategan du Preez

LL du Preez

https://orcid.org/0000-0002-9301-6348

The original article has been corrected.

The online version of the original article can be found at https://oi.org/ 10.1007/s00894-020-4350-7

Jan-G Vermeulen

VermeulenJ@ufs.ac.za

1 Department of Microbial, Biochemical and Food Biotechnology, Faculty of Agricultural Sciences, University of the Free State,

Bloemfontein, South Africa

2 Department of Haematology and Cell Biology, Faculty of Health Sciences, University of the Free State, Bloemfontein, South Africa

3 Division of Virology, Faculty of Health Sciences, University of the Free State, Bloemfontein, South Africa

4 National Health Laboratory Service, Universitas,

Bloemfontein, South Africa 